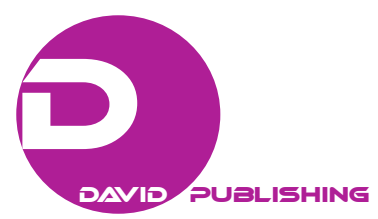

\title{
Spillover Effects of U.S. Quantitative Easing: Evidence From Global Bond Markets
}

\author{
Haiming $\mathrm{Yu}$ \\ Zhejiang University of Science \& Technology, Hangzhou, China \\ Baiding $\mathrm{Hu}$ \\ Lincoln University, Canterbury, New Zealand \\ Christopher Gan \\ Lincoln University, Canterbury, New Zealand
}

\begin{abstract}
This study empirically examines the U.S. quantitative easing (QE) spillover effects on the global bond markets. With a novel measurement of the U.S. latest unconventional monetary shocks, we find that the U.S. QE policy shocks significantly lower the bond yields in developed markets during the entire U.S. QE phase. However, our results also suggest that not all U.S. monetary policy shocks at this period have the pronounced spillover effects on the global bond market. Moreover, the different responses between the advanced and emerging markets also suggest the potential direction of the global portfolio rebalancing activities, as well as the capital flows in global bond markets.
\end{abstract}

Keywords: quantitative easing (QE), monetary policy shocks, spillover effect

\section{Introduction}

After the collapse of Lehman Brothers in September 2008, major economies started various unconventional monetary policies to spur their depressed economies. Among all, quantitative easing (QE) seemed to be the most popular one (Klyuev, De Imus \& Srinivasan, 2009). It aims at lowering the long-term interest rates with the central bank reserves to purchase large amounts of long-term securities (Benford, Berry, Nikolov, Young \& Robson, 2009; Bernanke, Reinhart \& Sack, 2004; Blinder, 2010). The general idea is that asset purchases can reduce interest rates with different maturities, and this is expected to help expand the level of income and employment (Chen, Curdia \& Ferrero, 2012). The large scale of assets purchase programs in the U.S. can generate pronounced impacts on the market and, as a result, it became the standard approach for most central banks after the 2008 global financial crisis (De Grauwe \& Ji, 2015). Given the growing interdependence among the global financial markets (especially with the U.S. market), the U.S. QE effects were certain to spill over to other markets and economies (Chen, Filardo, He \& Zhu, 2012).

In this paper, we examine the spillover effects of the U.S. unconventional monetary policy surprises on bond yields in global long-term bond markets using the DCC-MGARCH framework. Our results suggest that

Haiming Yu, lecturer, School of Economics and Management, Zhejiang University of Science \& Technology, Hangzhou, China. Baiding Hu, senior lecturer, Department of Global Value Chains and Trade, Lincoln University, Canterbury, New Zealand.

Christopher Gan, professor, Department of Accounting and Finance, Lincoln University, Canterbury, New Zealand. 
within each U.S. QE period, there is limited evidence supporting the pronounced spillover effects from the U.S. QE policy shocks to short-term assets (USQEPSSA). However, in terms of the U.S. QE policy shocks to long-term assets (USQEPSLA), they can significantly reduce most global bond yields (especially in the developed bond markets) throughout the three U.S. QE rounds. These results are in accordance with the fact that the U.S. QE policy of keeping lower future rates has been anticipated by the market while the long-lasting purchase of U.S. long-term securities brings consistent shocks to the bond markets beyond the U.S. economy.

The rest of the paper is organized as follows. Section 2 briefly reviews the literature on the QE spillover effects on global market. We then identify the U.S. QE policy shocks on both short- and long-term assets. The data and the econometric models are described in Section 3. Section 4 presents the empirical results for the spillover effects of U.S. QE policies on global bond yields and Section 5 concludes the paper.

\section{Literature Review}

\section{QE Spillover Effects on the Global Markets}

The literature on the U.S. QE policy effects on the financial markets has expanded since the launch of the U.S. QE policy. Initially, researchers, such as Gagnon, Raskin, Remache, and Sack (2011) and Swanson, Reichlin, and Wright (2011) employed the event study method to assess how the U.S. QE policy affected the domestic economy. They found that both the U.S. QE1 and QE2 policies had significant impacts on stimulating the domestic economy and markets. Since then, the research interest in the U.S. spillover effects, especially the spillover effects of the U.S. QE policies, has rapidly increased.

For example, Neely (2015) examined the U.S. QE spillover effects on long-term foreign bond yields from five advanced markets based on the event study method. The author found a significant decline for all bond yields and these prices change closely followed the U.S. QE announcements. Gambacorta, Hofmann, and Peersman (2014) estimated the U.S. QE spillover effects on eight developed markets with a panel VAR model and found a temporary rise in consumer prices and weaker and less persistent impacts than the ones triggered by the conventional monetary policy.

Besides the studies of the U.S. QE spillover effects on the developed markets, some researchers have investigated the U.S. QE spillover effects on the emerging markets. For example, Miyakoshi, Shimada, and Li (2017) applied the VAR model to examine the responses from eight Asian emerging markets towards the U.S. QE policy shocks and found that the U.S. QE policy contributed to the significant stock price increases in the sample markets. Kryzanowski, Zhang, and Zhong (2017) examined the U.S. QE spillover effects on the cross-market correlations among stocks, bonds, and forward contracts for 31 markets. Incorporating the different U.S. QE indicators in the DCC-GARCH model, the authors found that the U.S. QE policies had considerably different spillover effects on the cross-market correlations from the impacts triggered by the conventional U.S. monetary policy.

Nevertheless, though compared to the event study methods, the DCC-MGARCH and the (panel) VAR frameworks applied in the above studies can better address the market interactions between different financial markets, these models may not consider other disturbances, such as the stock market performance. Therefore, it is essential to properly define the U.S. monetary policy shocks, in other words, the unexpected U.S. monetary policy changes before estimating the U.S. QE spillover effects. 


\section{Identification of the U.S. QE Policy Surprise}

There are two major challenging tasks in studying monetary policy shocks on asset returns (Bredin, Hyde \& Reilly, 2010; Kishor \& Marfatia, 2013). One is the endogeneity and the other is the identification of unexpected components of monetary policy changes. However, some researchers (such as Bredin et al., 2010; Rigobon \& Sack, 2004) have argued that the change in monetary policy and asset prices may influence each other, and the study of monetary policy is unlikely to include all potential influences, but the failure to account for any endogeneity is practically quite small. Moreover, some studies also provide evidence that central banks have little role in responding to asset prices and the endogeneity problems are limited in international interest rate differentials studies (Valente, 2009). Therefore, we assume that the endogeneity problem will not have a significant impact on our study as Bredin et al. (2010) suggested.

The key point of measuring monetary policy shock is to precisely identify the unexpected components of the monetary policy changes to the market. Based on the efficient market hypothesis (EMH), only monetary policy surprises can affect the asset prices. Hence, how to measure the monetary policy surprise becomes an essential problem in estimating the market responses triggered by the monetary policy changes.

Moreover, unlike conventional monetary policy shocks, the identification of unconventional monetary policy shocks (such as the QE policy shocks) generates new challenges (Glick \& Leduc, 2013; Wright, 2012). During the conventional monetary policy period (before the 2007 subprime loan crisis), short-term interest rates were free floating. The monetary policy shocks at that time could be measured by the changes of the federal funds futures contracts (Kuttner, 2001). However, in terms of unconventional ones, they contain not only the signals for future short-term interest rates, but also the changes of long-term interest rates. This impact on long-term interest rates is mainly through large-scale of long-term assets purchasing program. Therefore, we developed different measures to address these U.S. QE effects on different assets followed Kishorand Marfatia’s (2013) and Kuttner's (2001) method.

\section{Methodology}

\section{Data}

In order to assess the U.S. QE spillover effects on the global bond markets, we gather 10 daily long-term bond yield data series ${ }^{1}$ from 1 January 2007 to January 2016. The dataset includes both emerging markets and advanced markets to investigate if there is any difference between different markets towards the U.S. QE shocks. The markets include the United States (US), United Kingdom (UK), Japan (JP), China (CH), Brazil (BR), India (IN), Russia (RU), Australia (AU), France (FR), and Germany (GE). The daily stock return data will also be included to represent the changes of the stock market performance. In terms of developed economies (see from Table 1), they tend to have a lower average bond yield but with a higher volatility than their emerging market counterparts. The joint effects of depressed economy and large-scale asset purchasing programs can explain this.

Since the data is of daily frequency, the general macroeconomic variables, such as the GDP cannot be applied. Consequently, we consider the daily stock return as a proxy of the economic environment changes during the sample period suggested by previous study (Steeley \& Matyushkin, 2015). Similarly, when the Fed launched the U.S. QE policies, there were other similar policies implemented by other leading economies ${ }^{2}$.

\footnotetext{
${ }^{1}$ We apply the 10-year bond yield data to represent the long-term bond yield, since it is the main asset purchased by the Fed within each U.S. QE policy.

${ }^{2}$ For example, the Bank of England and the Bank of Japan also launched their QE policies at the same time.
} 
Hence, in order to control for the potential effects from the stock market performance in both the domestic and the leading economies, we incorporate the daily stock return from both the domestic market and the U.S., U.K., and Japan markets. The bond yield change and the stock return will be calculated as $\ln \left(P_{t} / P_{t-1}\right) * 100$.

\section{Identification of the QE Policy Shock}

We apply the method proposed by Kishor and Marfatia (2013) initialled by Kuttner (2001). The daily U.S. monetary policy shocks to short-term assets (MPSSA) are computed as:

$$
\Delta r_{t}^{M P S S A}=\frac{n_{s}}{n_{s}-v}\left(f_{s, v}^{0}-f_{s, v-1}^{0}\right)
$$

Where $\triangle r_{t}^{M P S S A}$ represents the daily U.S. MPSSA, $n_{s}$ is the number of days in month $(s), f_{s, v}^{0}$ is the current month federal futures price on day $(v)$ of the month $(s)$ and $f_{s, v-1}^{0}$ is the current-month federal futures price on day $(v-1)$. The model applies to every day within one month except for the first and last day. When the USMPSSA takes place on the first day of the month, its expectations would have been reflected in the spot rate in the last month, hence, the prior month federal futures rate on the last day, $f_{s-1, v-1}^{1}$ is used instead of $f_{s, v-1}^{0}$. Similarly, when the MPSSA takes place on the last day of the month, the difference in the 1-month federal futures rate is applied. This is due to the fact that the policy change happening on the last day of the month is unable to influence the current month's spot rate. Furthermore, in order to avoid amplifying the month-end noise, no scale adjustment is made when the USMPSSA happens within the last three days of the month.

We then multiply the variable $\Delta r_{t}^{M P S S A}$ calculated in Equation (1) with dummy variables (defined in Table 2) to obtain the USQEPSSA variables (shown in the second equation).

$$
U S Q E P S S A_{i, t}=\Delta r_{t}^{M P S S A} * d_{i}
$$

Table 1

Descriptive Statistics of Global Bond Yields

\begin{tabular}{llllllllll}
\hline Market & Mean & Median & Max & Min & Std. Dev. & Skewness & Kurtosis & JB & $P$-value \\
\hline US & 2.92 & 2.7373 & 5.29 & 1.39 & 0.91 & 0.52 & 2.37 & 141.74 & 0 \\
UK & 3.13 & 2.975 & 5.55 & 1.33 & 1.12 & 0.36 & 1.94 & 158.87 & 0 \\
JP & 1.04 & 1.029 & 1.97 & 0.20 & 0.43 & -0.01 & 1.92 & 113.62 & 0 \\
CH & 3.72 & 3.6 & 4.71 & 2.78 & 0.43 & 0.43 & 2.21 & 133.88 & 0 \\
BR & 4.61 & 4.585 & 11.13 & 2.24 & 1.18 & 0.41 & 4.14 & 193.24 & 0 \\
IN & 7.97 & 7.978 & 9.48 & 5.08 & 0.62 & -1.01 & 5.43 & 971.22 & 0 \\
RU & 8.55 & 7.874 & 16.24 & 6.26 & 2.03 & 1.27 & 4.11 & 749.07 & 0 \\
AU & 4.53 & 4.35 & 6.79 & 2.28 & 1.19 & -0.07 & 1.67 & 174.98 & 0 \\
FR & 2.87 & 3.019 & 4.84 & 0.35 & 1.14 & -0.37 & 2.15 & 122.83 & 0 \\
GE & 2.43 & 2.331 & 4.68 & 0.08 & 1.24 & 0.05 & 1.80 & 140.40 & 0 \\
\hline
\end{tabular}

Note. Source: Author's calculation based on the data from Bloomberg and Datastream.

The USQEPSSA $A_{i, t}$ variables represent the daily monetary policy shocks to short-term assets generated within the U.S. QE1, QE2, and QE3 periods. The dummy variables $d_{i}$ represents the time frame of each individual U.S. QE period decided by the federal QE announcements. In both cases, $i=1$, 2, and 3. Variable $\Delta r_{t}^{\text {MPSSA }}$ measures the daily USMPSSA during the entire sampling period.

Similarly, we calculate the U.S. QE policy shocks to long-term assets using the same method, but with 10-year treasury futures data as described in Equations (3) and (4). 


$$
\begin{gathered}
\Delta r_{t}^{M P S L A}=\frac{n_{s}}{n_{s}-v}\left(g_{s, v}^{0}-g_{s, v-1}^{0}\right) \\
U S Q E P S L A_{i, t}=\Delta r_{t}^{M P S L A} * d_{i}
\end{gathered}
$$

\section{Empirical Model}

In order to examine the U.S. QE spillover effects on the global bond markets, we apply the DCC-MGARCH framework developed by Engle (2002) as follows:

$$
\Delta Y_{t}=C_{1}+a_{i} R_{t}^{i}+C_{2} \Delta Y_{t-1}+b_{i} \text { USQEPSSA }_{i, t}+m_{i} \text { USQEPSLA }_{i, t}+\varepsilon_{t}
$$

Where $\Delta Y$ is the change of the yield at time $(t)$ for each bond market, $R_{t}^{i}$ represent the daily stock return ${ }^{3}$ at both domestic and international levels. These stock returns are calculated to measure the effects of stock performance on the bond yields from both local and three leading economies (U.S., U.K., and Japan), respectively. The inclusion of domestic stock performance in each equation is due to the important effects that the domestic stock performance has on the bond yields. The stock performances from the U.S., U.K., and Japan represent the impacts from the international stock markets, since these economies play an important role in international financial markets. USQEPSSA $A_{i, t}$ and $U S Q E P S L A_{i, t}$ are the U.S. monetary policy shocks to shortand long-term assets within each U.S. QE phase, respectively.

Table 2

Different U.S. QE Rounds

\begin{tabular}{lll}
\hline Dummy variable & 1 & 0 \\
\hline $\mathrm{D}_{1}$ & 25 November, 2008 to 25 March, 2010 & Otherwise \\
$\mathrm{D}_{2}$ & 3 November, 2010 to 25 June, 2011 & Otherwise \\
$\mathrm{D}_{3}$ & 13 September, 2012 to 29 October, 2014 & Otherwise \\
\hline
\end{tabular}

The residuals of each mean equation are modeled as follows:

$$
h_{t}=C_{0}+\alpha \varepsilon_{t-1}^{2}+\beta h_{t-1}^{2}
$$

This is the first step in estimating the univariate GARCH $(1,1)$ model. The second step in estimating the conditional correlation will be modeled based on the univariate results and the residual $\varepsilon_{t}$ generated from all three mean equations in a standard GARCH model as:

$$
\varepsilon_{t}=D_{t} v_{t} \sim N\left(0, H_{t}\right)
$$

Where $\varepsilon_{t}$ is a $k \times 1$ column vector of residual yields of $Y, k$ is the number of markets included, $v_{t}$ is a $k \times$ 1 column vector of standardized residual yields. $H_{t}$ is a $k \times k$ matrix of dynamic variances. Specifically,

$$
H_{t}=D_{t} R_{t} D_{t}
$$

Where $D_{t}$ is a $k \times k$ diagonal matrix of dynamic standard deviation of residuals in mean Equation (5), with $D_{t}=\operatorname{diag}\left\{\sqrt{h_{t}}\right\}$. Where each $h_{t}$ is calculated from the univariate GARCH $(1,1)$ model in Equation (6).

The framework also consists of a specific DCC structure $R_{t}$, which is a $k \times k$ matrix of dynamic correlations and can be expressed as:

$$
R_{t}=Q_{t}^{*-1} Q_{t} Q_{t}^{*-1}
$$

The dynamic conditional correlation structure is then given by Equation (8):

$$
Q_{t}=(1-\alpha-\beta) \bar{Q}+\alpha v_{t-1} v_{t-1}^{\prime}+\beta Q_{t-1}
$$

\footnotetext{
${ }^{3}$ Since this study examines the bond yield changes on a daily frequency, it is difficult to incorporate common indicators for economic change, such as, the change in GDP, we therefore use the daily stock return variable as a proxy, as suggested by Steeley and Matyushkin (2015).
} 
Where $Q_{t}$ is the conditional variance-covariance matrix of residuals with its unconditional variance-covariance matrix $\bar{Q}$ obtained from the GARCH $(1,1)$ process in Equation (4). $Q_{t}^{*}$ is a diagonal matrix with the square root of the diagonal elements of $Q_{t}$, and $Q_{t}^{*}=\operatorname{diag}\left\{\sqrt{Q_{t}}\right\} . v_{t}=\varepsilon_{t} / \sqrt{h_{t}}$, the scalars $\alpha$ and $\beta$ are non-negative, which satisfy $\alpha+\beta<1$.

The parameters in both Equations (6) and (10) can represent the time-varying volatility spillover effects from the U.S. QE shocks to different markets. Unlike the estimation in the univariate GARCH model independently, the DCC-MGARCH model jointly considers these interdependencies among the markets and the exogenous U.S. QE shocks, which can better identify the spillover effects triggered by the U.S. QE policies.

\section{Empirical Results}

The DCC-MGARCH estimation results are presented in Table 3. Based on the results, we conclude that the domestic stock market performance (column 1 in Table 3) plays a significant role in most of the sample economies (except for China). Moreover, for most advanced markets, their domestic stock markets have a positive impact on the domestic bond yields. This suggests that the domestic bond market may be benefit for the growth in the domestic stock market.

Furthermore, the U.S. and U.K. stock changes (columns 2 and 3 in Table 3) also positively affect most developed bond markets, while in the case of Japan (column 4 in Table 3), the effects are less significant. This indicates that for most developed bond markets, a stronger growth in the U.S. and U.K. stock markets can result in a significant increase in the bond yields in developed economies. It is no surprising since for most economies, stock performance is positively correlated with their domestic economic development, as well as the global environment. A positive stock change on the U.S. and U.K. markets not only suggests an up-ward trend in both economies, but also indicates a better global economic environment. This increasing global economic environment will then result in the booming of global bond markets.

Moreover, the positive DCC coefficients in all the tables (the last two columns in Table 3) suggest a dynamic correlation between the leading bond markets and the rest of the bond markets. The sum of all estimated coefficients is less than one, indicating that the dynamic correlation between the global bond markets and the leading bond markets is stationary and mean reverting ${ }^{4}$.

Table 3 also presents the spillover effects of both USQEPSSA and USQEPSLA on the global bond markets simultaneously (columns 5-10, respectively). The empirical results indicate that only a few bond yields (Russia, Brazil, and Japan) have been significantly affected by the USQEPSSA during the U.S. QE periods. For most global bond markets, especially the developed bond markets, there is no pronounced evidence of spillover effects from the USQEPSSA variables. Not surprisingly, as addressed in some studies (Wright, 2012; Glick \& Leduc, 2013), at the time of liquidity trap, short-term interest rates are locked at zero lower bound and the U.S. QE policies are designed to influence the long-term interest rates. Therefore, compared to the long-term assets, short-term assets are less affected by these policies since they are not closely-related substitute for the long-term U.S. treasury bonds.

\footnotetext{
${ }^{4}$ Due to the page limits, we did not report the dynamic correlation plots between the U.S. bond market and other markets.
} 
Table 3

Short-Term and Long-Term U.S. QE Shocks on Global Bond Markets

\begin{tabular}{|c|c|c|c|c|c|c|c|c|c|c|c|c|c|}
\hline Market & $a_{1}$ & $a_{2}$ & $a_{3}$ & $a_{4}$ & $b_{1}$ & $b_{2}$ & $b_{3}$ & $m_{1}$ & $m_{2}$ & $m_{3}$ & $c_{2}$ & $\alpha$ & $\beta$ \\
\hline $\mathrm{CH}$ & -0.013 & $0.073 * * *$ & $-0.064 * * *$ & 0.016 & 1.366 & 1.325 & 0.877 & $-0.034 *$ & 0.018 & -0.006 & $-0.218 * * *$ & $0.009 * * *$ & $0.956 * * *$ \\
\hline $\mathrm{BR}$ & $-0.172 * * *$ & -0.046 & $-0.125 * * *$ & 0.005 & $3.397 * *$ & $-14.316^{* *}$ & -3.404 & $-0.094 * * *$ & $-0.268 * * *$ & $-0.179 * * *$ & -0.026 & $0.007 * *$ & $0.965 * * *$ \\
\hline IN & $-0.054 * * *$ & -0.002 & 0.006 & $0.029 * * *$ & -0.669 & -0.869 & -2.246 & -0.007 & 0.001 & 0.003 & $0.076^{* * *}$ & 0.012 & $0.909 * * *$ \\
\hline RU & $-0.032 * * *$ & $-0.036^{*}$ & $-0.074 * * *$ & $-0.074 * * *$ & $15.372^{* * *}$ & $18.365^{* * *}$ & $27.65^{* * *}$ & -0.029 & $0.042 * *$ & -0.003 & $-0.203 * * *$ & $0.006^{* *}$ & $0.975^{* * *}$ \\
\hline $\mathrm{AU}$ & $0.031 *$ & $0.055^{* *}$ & $0.086 * * *$ & $0.279 * * *$ & -1.924 & -1.206 & 4.119 & $-0.04 * *$ & -0.02 & $-0.11 * * *$ & $-0.171 * * *$ & $0.014 * * *$ & $0.92 * * *$ \\
\hline FR & $0.116^{* * *}$ & $0.11^{* * *}$ & $0.171^{* * *}$ & -0.022 & -0.832 & 3.857 & -2.497 & $-0.084 * * *$ & $-0.085^{* * *}$ & $-0.214^{* * *}$ & 0.032 & $0.01^{* * *}$ & $0.983 * * *$ \\
\hline GE & $0.275^{* * *}$ & $0.115^{* * *}$ & $0.189 * * *$ & -0.013 & -1.024 & 3 & 5.318 & $-0.108 * * *$ & $-0.115 * * *$ & $-0.354 * * *$ & 0.003 & $0.012 * * *$ & $0.965 * * *$ \\
\hline US & $0.669 * * *$ & $0.669 * * *$ & $0.108 * * *$ & -0.006 & $-1.978 * *$ & -2.138 & -10.657 & $-0.282 * * *$ & $-0.293 * * *$ & $-0.353 * * *$ & $-0.042 *$ & $0.008^{* *}$ & $0.978 * * *$ \\
\hline UK & $0.326 * * *$ & $0.15^{* * *}$ & $0.326 * * *$ & 0.02 & -1.06 & 5.308 & 2.447 & $-0.107 * * *$ & $-0.106 * * *$ & $-0.268 * * *$ & -0.031 & $0.008^{* *}$ & $0.978 * * *$ \\
\hline $\mathrm{JP}$ & $0.444 * * *$ & -0.011 & 0.037 & $0.444 * * *$ & 0.405 & $18.689 * *$ & $-27.021 * * *$ & 0.006 & 0.041 & $-0.06^{*}$ & $-0.04 *$ & $0.008 * *$ & $0.978 * * *$ \\
\hline
\end{tabular}

Notes. ${ }^{* * *}, * *$, and $*$ represent significance at the $1 \%, 5 \%$, and $10 \%$ levels, respectively. Source: Author's calculation. 
In terms of the USQEPSLA variables, they significantly reduce most bond yields (especially the bond yields in the developed markets) across the entire U.S. QE periods. This result suggests a pronounced global portfolio rebalancing effect from the U.S. QE policies. Moreover, this pronounced U.S. QE spillover effects on the bond yields in especially developed markets also indicate the main direction of the global portfolio rebalancing activities. Thus, from the investors' perspective, the long-term assets on the developed markets are the main substitute for the long-term U.S. securities. In other words, the market participants tend to purchase long-term assets in the developed markets in place of the long-term U.S. securities in their investment portfolios.

\section{Conclusions}

This paper assesses U.S. QE spillover effects on 10 long-term government bond yields on a daily basis. In order to better measure the effects of shocks generated from U.S. QE policies, we incorporate both the short-term and long-term U.S. QE policy shocks in our DCC-MGARCH model. These two types of shocks were constructed using daily federal funds futures and the 10-year treasury futures data, which enables us to examine the U.S. QE spillover effects towards different assets.

The empirical results show that the USQEPSSA has insignificant spillover effects on most global bond yields. This is in accordance with the fact that U.S. QE policies play less important role on affecting the short-term interest rates. During the zero lower bound period, the policy announcements of keeping lower future short-term interest rates alone cannot consistently provide significant shocks to the markets, since the short-term interest rates are already close to zero.

In terms of the USQEPSLA, the results show significant spillover effects for most developed markets throughout all three U.S. QE phases. This indicates that the U.S. QE policies significantly affect the developed bond markets. As long as the Federal Reserve keeps purchasing the long-term assets, the global portfolio rebalancing activities will persistently affect the developed bond markets.

The results also have important practical implications for both the policy makers as well as the market participants. The pronounced U.S. QE spillover effects indicate that, for especially the policy makers of developed economies which did not have any asset purchasing program, they should take potential external policy shocks into consideration when launching their new policies and better enhance the cross-market policy cooperation in order to avoid over-stimulating.

In terms of market participants, the lack of co-movements between the developed bond markets (especially the U.S. bond market) and the emerging bond markets, as well as the insignificant spillover effects suggest the potential diversification benefits. The more pronounced U.S. QE spillover effects on the developed bond markets compared to the emerging bond markets also suggest that investors tend to substitute U.S. securities with assets in developed markets in their investment portfolios. Meanwhile, the persistent significant long-term U.S. QE spillover effects on the developed bond yields indicate that investors in developed bond markets should keep an eye on the monetary easing policies in the U.S. when investing in the developed markets and may re-allocate their assets into the markets which are less subjected to the exogenous U.S. policy shocks (such as the emerging markets) for diversification benefits. 


\section{References}

Benford, J., Berry, S., Nikolov, K., Young, C., \& Robson, M. (2009). Quantitative easing. Bank of England Quarterly Bulletin, 49(2), 90-100.

Bernanke, B., Reinhart, V., \& Sack, B. (2004). Monetary policy alternatives at the zero bound: An empirical assessment. Brookings Papers on Economic Activity, 2004(2), 1-100.

Blinder, A. S. (2010). Quantitative easing: Entrance and exit strategies (digest summary). Federal Reserve Bank of St. Louis Review, 92(6), 465-479.

Bredin, D., Hyde, S., \& Reilly, G. O. (2010). Monetary policy surprises and international bond markets. Journal of International Money and Finance, 29, 988-1002.

Chen, H., Curdia, V., \& Ferrero, A. (2012). The macroeconomic effects of large-scale asset purchase programmes. The Economic Journal, 122(564), F289-F315.

Chen, Q., Filardo, A. J., He, D., \& Zhu, F. (2012). International spillovers of central bank balance sheet policies. BIS Paper, No. 66. Basel, Switzerland: Bank for International Settlements.

De Grauwe, P., \& Ji, Y.(2015). Quantitative easing in the Eurozone: It's possible without fiscal transfers. Retrieved from https://voxeu.org/article/quantitative-easing-eurozone-its-possible-without-fiscal-transfers

Engle, R. (2002). Dynamic conditional correlation: A simple class of multivariate generalized autoregressive conditional heteroskedasticity models. Journal of Business \& Economic Statistics, 20(3), 339-350.

Gagnon, J., Raskin, M., Remache, J., \& Sack, B. (2011). The financial market effects of the Federal Reserve’s large-scale asset purchases. International Journal of Central Banking, 7, 3-43.

Gambacorta, L., Hofmann, B., \& Peersman, G. (2014). The effectiveness of unconventional monetary policy at the zero lower bound: A cross-country analysis. Journal of Money, Credit and Banking, 46(4), 615-642.

Glick, R., \& Leduc, S. (2013). Unconventional monetary policy and the dollar. FRBSF Economic Letter. Retrieved from https://www.frbsf.org/economic-research/files/wp2015-18.pdf

Kishor, N. K., \& Marfatia, H. A. (2013). The time-varying response of foreign stock markets to U.S. monetary policy surprises: Evidence from the federal funds futures market. Journal of International Financial Markets, Institutions and Money, 24, $1-24$.

Klyuev, M. V., De Imus, P., \& Srinivasan, M. K. (2009). Unconventional choices for unconventional times credit and quantitative easing in advanced economies. Washington, D.C.: International Monetary Fund.

Krishnamurthy, A., Vissing-Jorgensen, A., Gilchrist, S., \& Philippon, T. (2011). The effects of quantitative easing on interest rates: Channels and implications for policy/comments and discussion. Brookings Papers on Economic Activity, 2011, 215-287.

Kryzanowski, L., Zhang, J., \& Zhong, R.(2017). Cross-financial-market correlations and quantitative easing. Finance Research Letters, 20, 13-21.

Kuttner, K. N. (2001). Monetary policy surprises and interest rates: Evidence from the Fed funds futures market. Journal of Monetary Economics, 47(3), 523-544.

Miyakoshi, T., Shimada, J., \& Li, K.-W. (2017). The dynamic effects of quantitative easing on stock price: Evidence from Asian emerging markets, 2001-2016. International Review of Economics \& Finance, 49, 548-567.

Neely, C. J. (2015). Unconventional monetary policy had large international effects. Journal of Banking \& Finance, 52, $101-111$.

Rigobon, R., \& Sack, B. (2004). The impact of monetary policy on asset prices. Journal of Monetary Economics, 51(8), 1553-1575.

Steeley, J. M., \& Matyushkin, A. (2015). The effects of quantitative easing on the volatility of the gilt-edged market. International Review of Financial Analysis, 37, 113-128.

Swanson, E. T., Reichlin, L., \& Wright, J. H. (2011). Let’s twist again: A high-frequency event-study analysis of operation twist and its implications for QE2. Brookings Papers on Economic Activity, 2011, 151-207.

Valente, G. (2009). International interest rates and U.S. monetary policy announcements: Evidence from Hong Kong and Singapore. Journal of International Money and Finance, 28(6), 920-940.

Wright, J. H. (2012). What does monetary policy do to long-term interest rates at the zero lower bound? The Economic Journal, 122(564), F447-F466. 